\title{
Functionalized polyanilines: influence of the surface morphology on the electrophysical and sensory properties of thin films based on them
}

\author{
R. B. Salikhov ${ }^{\dagger, 1}$, Yu. N. Biglova ${ }^{1}$, I. N. Mullagaliev ${ }^{1}$, T. R. Salikhov ${ }^{1}$, A. G. Mustafin ${ }^{1,2}$ \\ ${ }^{\dagger}$ salikhovrb@yandex.ru \\ ${ }^{1}$ Bashkir State University, Ufa, 450076, Russia \\ ${ }^{2}$ Ufa Institute of Chemistry, UFRC RAS, Ufa, 450054, Russia
}

\begin{abstract}
The effect of the morphology of polyaniline (PANI) and its copolymers on the electrical conductivity and sensory sensitivity to air humidity of thin-film structures based on them has been studied. Polyaniline and three new related copolymers have been synthesized: poly (aniline-co-ortho-toluidine), poly\{aniline-co-2-(cyclohec-2-en-1-yl)aniline\}, poly\{aniline-co-2(cyclopent-2-en-1-yl)aniline\}. Using a scanning electron microscope, the surface morphology of thin films obtained from a solution of synthesized polymers by spin coating on sitall substrates was studied. The morphology of the samples obtained from copolymers with ortho-toluidine and new PANI derivatives differs significantly from PANI itself, which indicates the effect of substituents on the supramolecular structure. Since high-molecular-weight samples were synthesized under identical conditions, the revealed differences in morphology are directly related to the mechanism of interaction of monomeric units. Large hollow spheres were obtained by the mechanism of self-assembly of a copolymer sample based on ortho-toluidine. It is known, that such a morphology is a potentially useful structure for obtaining various sensor devices. On the basis of PANI and its copolymers, samples of resistive thin-film structures were prepared and the dependence of their electrical conductivity on the value of the relative air humidity was measured. The influence of the surface morphology of PANI films and its copolymers on the sensor sensitivity to air humidity was experimentally revealed, and the prospects of using the studied films in humidity sensors were shown. It was found that at maximum values of relative air humidity of $90 \%$, films of poly(aniline-co-orthotoluidine) copolymer had the highest conductivity. Samples of sensors based on unmodified PANI demonstrate the lowest conductivity. It should be noted that the resistive sensors on thin films of poly\{aniline-co-2-(cyclohec-2-en-1-yl)aniline\} have the most uniform and close to linear characteristic in the range of $20-90 \%$ humidity.
\end{abstract}

Keywords: polymers, polyanilines, thin-film structures, air humidity.

УДК: 54.03

\section{Функционализированные полианилины: влияние морфологии поверхности тонких пленок на их основе на электрофизические и сенсорные свойства}

\author{
Салихов Р. Б. ${ }^{\dagger, 1}$, Биглова Ю. Н. ${ }^{1}$, Муллагалиев И. Н. ${ }^{1}$, Салихов Т. Р. ${ }^{1}$, Мустафин А. Г. ${ }^{1,2}$ \\ ${ }^{1}$ Башкирский государственный университет, Уфа, 450076, Россия \\ ${ }^{2}$ Уфимский институт химии УФИЦ РАН, Уфа, 450054, Россия
}

Исследовано влияние морфологии полианилина (ПАНИ) и его сополимеровна электропроводимость и сенсорную чувствительность к влажности воздуха тонкопленочных структур на их основе. Синтезированы полианилин и три новых родственных ему сополимера: поли (анилин-со-орто-толуидин), поли\{анилин-со-2-(циклогек-2-ен-1-ил) анилин\}, поли\{анилин-со-2-(циклопент-2-ен-1-ил)анилин\}. С помощью сканирующего электронного микроскопа была изучена морфология поверхности тонких пленок, полученных из раствора синтезированных полимеров методом центрифугирования на ситалловых подложках. Морфология полученных образцов из сополимеров с орто-толуидином и новыми производными ПАНИ значительно отличается от самого ПАНИ, что свидетельствует 
о влиянии заместителей на надмолекулярную структуру. Поскольку высокомолекулярные образцы синтезированы в идентичных условиях, выявленные отличия в морфологии непосредственно связанны с механизмом взаимодействия мономерных единиц. По механизму самосборки сополимерного образца на основе орто-толуидина получены полые сферы большого размера. Подобная морфология, как известно, является потенциально полезной структурой для получения различных сенсорных устройств. На основе ПАНИ и его сополимеров изготовлены образцы резистивных тонкопленочных структур и измерена зависимость их электропроводности от величины относительной влажности воздуха. Экспериментально обнаружено влияние морфологии поверхности пленок ПАНИ и его сополимеров на сенсорную чувствительность к влажности воздуха и показана перспективность применения исследованных пленок в датчиках влажности. Установлено, что при максимальных значениях относительной влажности воздуха в 90\% наибольшей проводимостью обладают пленки сополимера поли(анилин-со-ортотолуидин)а. Образцы датчиков на основе немодифицированного ПАНИ демонстрируют наименьшую проводимость. Следует отметить, что самую равномерную и близкую к линейной характеристику в интервале 20 - $90 \%$ влажности имеют резистивные датчики на тонких пленках поли $\{$ анилин-со-2-(циклогек-2-ен-1-ил)анилин $\}$ а.

Ключевые слова: полимеры, полианилины, тонкопленочные структуры, влажность воздуха.

\section{Introduction}

Recently, research is being actively carried out on new polymer materials that have high conductivity and can be used in electronics [1-3]. Polymer electronics are rapidly evolving as a cheap, flexible, and environmentally friendly alternative to classic silicon electronics. Due to the problems associated with environmental pollution and increased environmental problems, the work on the synthesis of new polymeric substances is being actualized for the development of electronic sensors on their basis, including air humidity sensors [4-6].

As one of the brightest representatives of such polymeric materials, polyaniline (PANI) has the following characteristics: redox activity, paramagnetic properties, electronic and ionic conductivity. The polymer is successfully used in sensors, as anti-static electrically conductive coatings, to protect metals from corrosion [7-9]. Nevertheless, PANI dissolves unsatisfactorily in organic solvents, which significantly hinders its use. The new polyaniline copolymers obtained and studied in this work additionally acquire such characteristics as improved solubility in typical organic solvents and good adhesion to the substrate. In this regard, it becomes possible to more simplify the production of uniform thin-film coatings of improved quality, for example, by spin coating and dipping.

The use of PANI in sensors involves the use of physical changes that occur in highmolecular weight objects exposed to various chemicals at the level of the molecular and macroscopic structure of polymers [10-12]. However, the set of requirements for thin films made of polymeric materials is not limited only by their sufficiently high conductive properties. Since most materials are not indifferent to moisture, choosing the right polymer is rather difficult. Nevertheless, PANI, which is distinguished by its resistance to moisture, additionally possesses both thermal stability and high chemical resistance to aggressive substances, the presence of which is possible in the environment. Moreover, it has to withstand the harsh and harsh conditions often found in industrial environments.

In light of the above, the aim of this work was to study the effect of the surface morphology of thin films of polyaniline and copolymers based on it on the electrical conductivity and sensory sensitivity to air humidity.

\section{Experimental part}

\subsection{Materials}

Commercially available reagents and solvents (Acros, Fluka, Sigma-Aldrich) were used (unless otherwise stated) without further purification: aniline, ortho-toluidine, ammonium persulfate, hydrochloric acid, acetonitrile, N, $\mathrm{N}$-dimethylformamide (DMF), dimethyl sulfoxide (DMSO), $\mathrm{N}$-methylpyrrolidone, tetrahydrofuran (THF), toluene, ethyl acetate, chloroform.

The starting monomers, aniline and ortho-toluidine, were distilled under reduced pressure before use; 2-(cyclohex-2-en-1-yl)aniline and 2-(cyclopent-2-en-1-yl) aniline were synthesized according to a known method [13], distilled under vacuum to remove oxidized impurities, and characterized using modern spectral methods of analysis, the data of which coincide with those described in the literature (Fig. 1).<smiles>Nc1ccccc1</smiles>

aniline<smiles>Nc1ccccc1C1C=CCCC1</smiles>

2- (cyclohec-2-en-1-yl) aniline

Fig. 1. Starting monomers.

\subsection{Synthesis techniques}

All samples were obtained using an identical method of oxidative polymerization [14-16]. Initially, various monomers were dissolved in $0.2 \mathrm{M}$ hydrochloric acid, the total ratio of which was $0.1 \mathrm{M}$ (Table 1 ). In parallel, $0.125 \mathrm{M}$ ammonium persulfate was dissolved in $0.2 \mathrm{M}$ hydrochloric acid. Then the solutions were slowly mixed in a molar ratio of 
Table 1. Ratios of aniline and monomers.

\begin{tabular}{|c|c|c|}
\hline$($ Co)polymers & Monomer molar ratio & Yield in 24 hours, $\%$ \\
\hline $\mathbf{1}$ & aniline & 85 \\
\hline $\mathbf{2}$ & aniline: ortho-toluidine =1:3 & 79 \\
\hline $\mathbf{3}$ & aniline: 2- (cyclohec-2-en-1-yl) aniline $=1: 3$ & 71 \\
\hline $\mathbf{4}$ & aniline: 2- (cyclopent-2-en-1-yl) aniline $=1: 3$ & 75 \\
\hline
\end{tabular}

1.00:1.25 monomer/oxidizing agent. The reaction proceeded for 24 hours at room temperature with constant stirring.

The by-products of the polymerization process, ammonium sulfate and sulfuric acid, were removed by repeated washing of the precipitate with distilled water. The isolated product was dried under vacuum for 3 hours at $60^{\circ} \mathrm{C}$. The obtained highmolecular compounds have a powdery appearance of green-black color.

\subsection{Research methods}

The solubility of (co)polymers in the selected solvents was determined by equilibration of an excess amount of solid with a solvent by shaking in a Higuchi and Connors flask [17]. All analyzes were performed at atmospheric pressure and room temperature.

On the basis of four derivatives of polyaniline 1-4, samples of resistive sensors were made (Fig. 2). Sitall was used as a substrate; aluminum contacts were deposited on it by thermal sputtering in a vacuum chamber on a VUP-5 apparatus with a thickness of about $400 \mathrm{~nm}$, the gap between the contacts was $50 \mu \mathrm{m}$. Films of PANI and copolymers based on it were applied to the gap region by centrifugation from a solution of $\mathrm{N}$-methylpyrrolidone. The rotation time was 2 minutes, the speed after 1 minute was increased from 400 to $1000 \mathrm{rpm}$. To remove residual solvent, the samples were subjected to thermal annealing by heating to $50^{\circ} \mathrm{C}$ for 20-25 minutes. The thickness of thin polymer films was controlled based on the analysis of AFM images obtained with the "Nanoscan 3D" and was $150 \mathrm{~nm}$.

In the experiments we used: MASTECH power supplies, DC POWER SUPPLY HY3005D-2, a DMM4020 multimeter

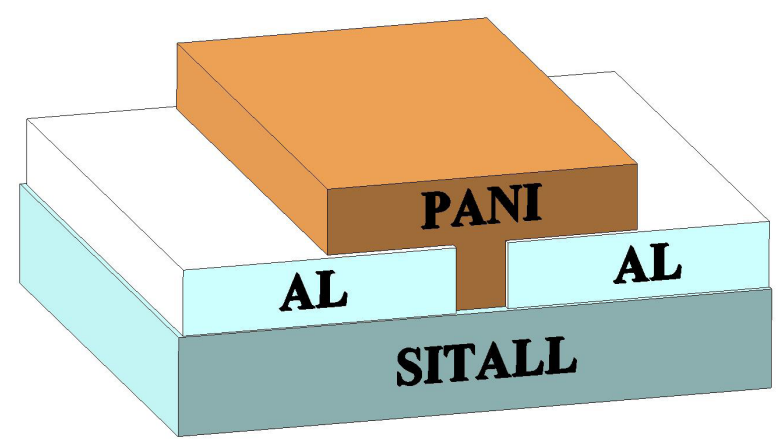

Fig. 2. (Color online) Structure of a thin film resistive sensor.

as an ammeter, an Arduino Uno programmable controller, a laptop, and a DHT-11 humidity sensor.

A sample of the humidity sensor was placed under a cap containing a control humidity sensor and a water tank (Fig. 3). After that, the output signal values were taken at certain humidity values. The moisture growth rate was $\sim 3 \% / \mathrm{min}$. Moisture control was carried out using a DHT-11 sensor. The humidity values were transferred via the Arduino Uno and USB to the laptop screen. The measurements were carried out at room temperature $25^{\circ} \mathrm{C}$, the voltage on the samples was $5 \mathrm{~V}$.

The study of the microstructure of (co)polymers was carried out using a TESCAN MIRA 3 LMH high-resolution scanning electron microscope (SEM) equipped with a scattered electron and backscattered electron detector. The survey was carried out at an accelerating voltage of $10 \mathrm{kV}$ and a vacuum of the order of $10^{-3} \mathrm{~Pa}$.

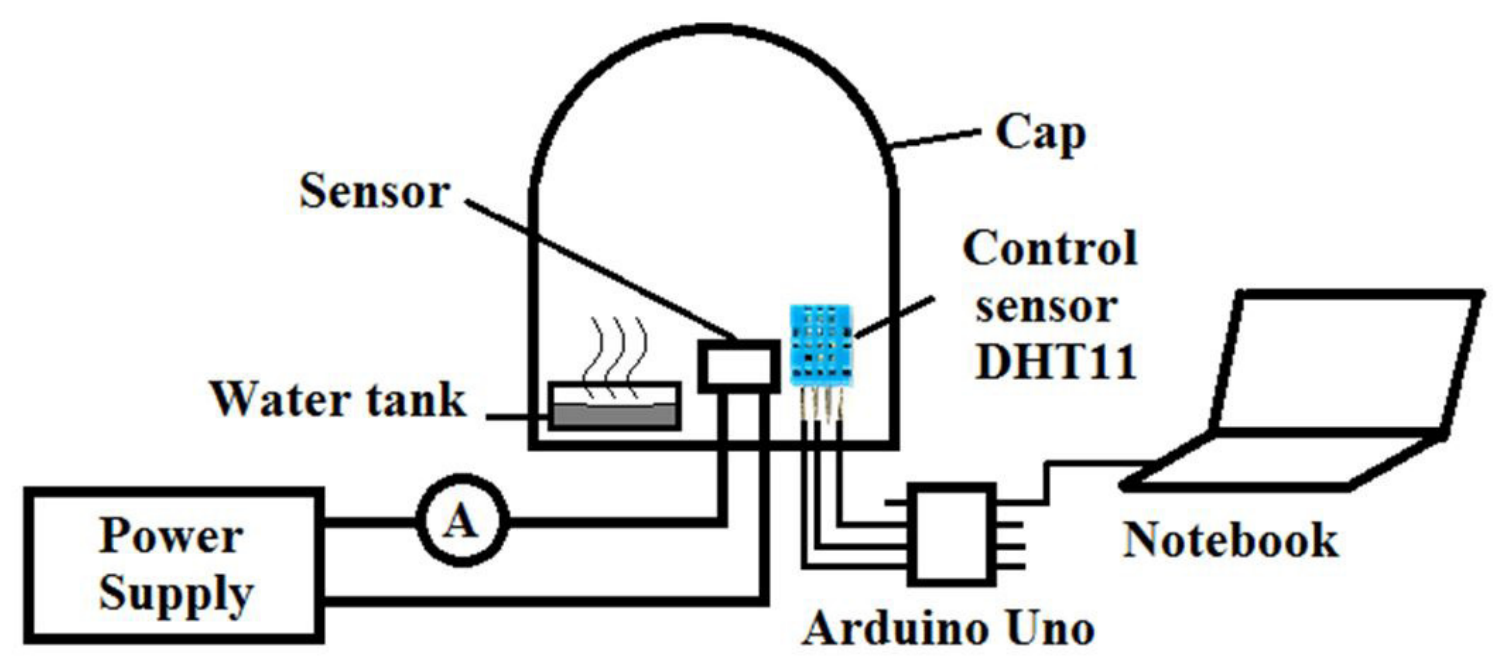

Fig. 3. (Color online) Measurement setup for current-voltage characteristics of sensor samples. 


\section{Results and discussion}

The chemical structures of the synthesized highmolecular compounds based on aniline and its functionalized derivatives are shown in Fig. 4.

As already noted, the main disadvantage of PANI is its unsatisfactory solubility in common organic solvents. Since the solubility reflects the amount of the solute per unit volume of the solvent, the solubility of the synthesized copolymers in typical organic solvents differing in polarity was studied. Based on the data presented in Table 2, it can be stated that the introduction of substituents into the aromatic ring of the polymer leads to a significant increase in its solubility in DMSO, N-methylpyrrolidone, and chloroform.

PANI and its copolymers have morphological flexibility characteristic only for them. This makes it possible to study the structure and properties relations of these nanoscale materials to develop potential applications for various types of morphologies. The morphology of the synthesized (co)polymers 1-4, investigated by SEM, revealed the following.

Oxidative polymerization of aniline and its derivatives leads to the production of a huge number of micro- and nanostructures that differ in size and shape and depend on the experimental conditions of the process [18]. As seen in Fig. 5, sample 1 has a fibrous nanostructure. The morphology of the obtained copolymer samples 2-4 differs significantly from PANI; therefore, a certain supramolecular structure is achieved by varying the substituents. High molecular weight products $2-\mathbf{4}$ are characterized by a spherical supramolecular structure; however, the sizes of the spheres of the compounds are very different, which should be attributed to the presence

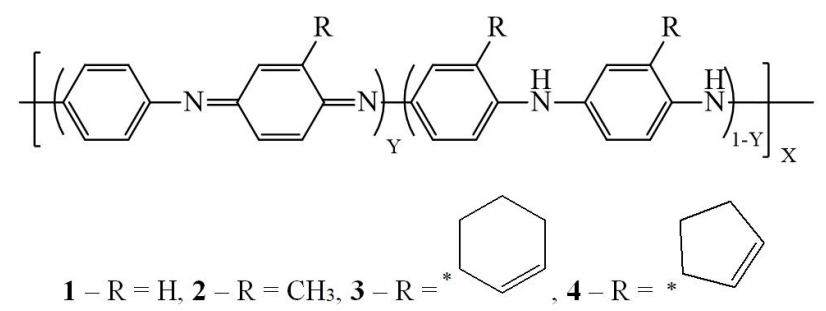

Fig. 4. Chemical structures: 1 - PANI, 2 - poly(aniline-co-orthotoluidine), 3 - poly\{aniline-co-2-(cyclohec-2-en-1-yl)aniline\}, 4 - poly\{aniline-co-2-(cyclopent-2-en-1-yl)aniline\}.

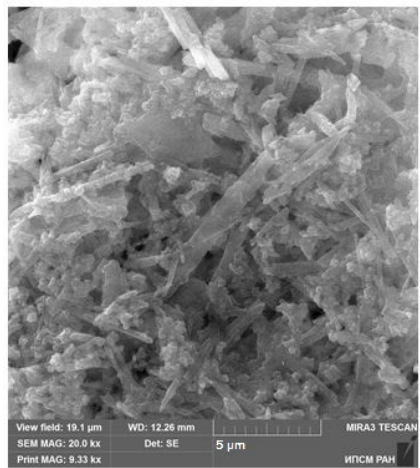

a

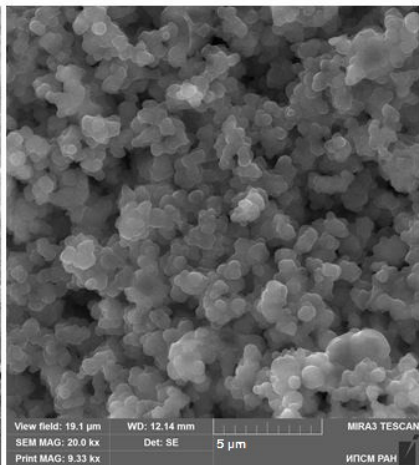

Table 2. Solubility of (co)polymers $\mathbf{1 - 4}$ in various typical organic solvents.

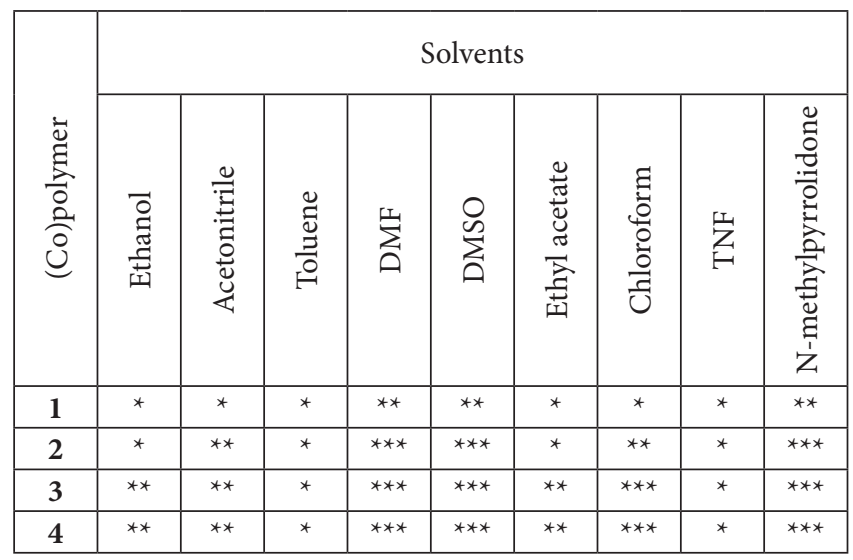

Note: Solubility was determined using $0.05 \mathrm{~g}$ of sample and $10 \mathrm{ml}$ of solvent.

*insoluble or poorly soluble $(<3 \%)$;

${ }^{* *}$ partially soluble $(>3,<7 \%)$;

${ }^{* * *}$ completely soluble $(>10 \%)$.

of substituents in the aromatic ring of the initial $\mathbf{1}$. Since the polymer samples were synthesized under identical conditions, the revealed differences in morphology are directly related to the mechanism of interaction of monomeric units $[19,20]$. For example, by the mechanism of self-assembly of copolymer sample 2 based on ortho-toluidine, as described in the literature for the homopolymer of ortho-toluidine $[21,22]$, large hollow spheres were obtained (Fig. 5 b). This morphology is known to be a potentially useful structure for obtaining various sensor devices [22]. Products 3 and 4 exhibit nanostructures with smaller globules (Fig. $5 \mathrm{c}, \mathrm{d}$ ). The study of the morphology of PANI films shows that the conductivity of the latter is influenced by the size of its globules [23].

Further, in accordance with the aim of the study, we measured the dependences of the current, flowing through the films of PANI and derivatives based on it, on humidity and on the relaxation time (sample recovery). According to the current value, the electrical conductivity values were calculated, which are indicated in the graphs (Fig. $6 \mathrm{a}$ and b). It can be seen that films of copolymer 2 exhibit the highest conductivity at maximum values of relative air humidity of $90 \%$. Films 3 and $\mathbf{4}$ have more than 2 times less

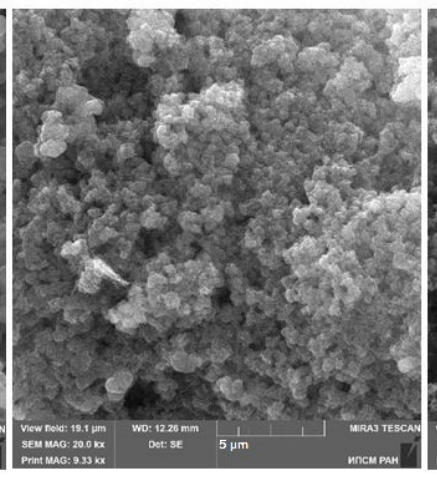

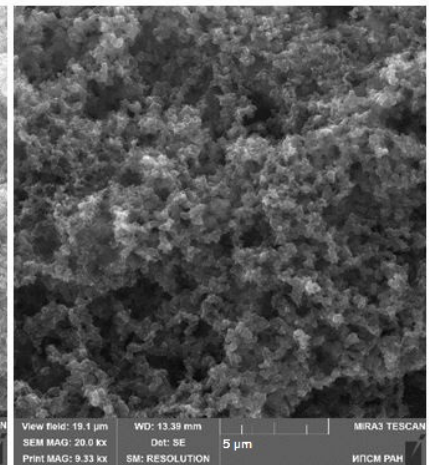

d

Fig. 5. SEM images of samples of the obtained (co)polymers: 1 (a); 2 (b); 3 (c); 4 (d). 


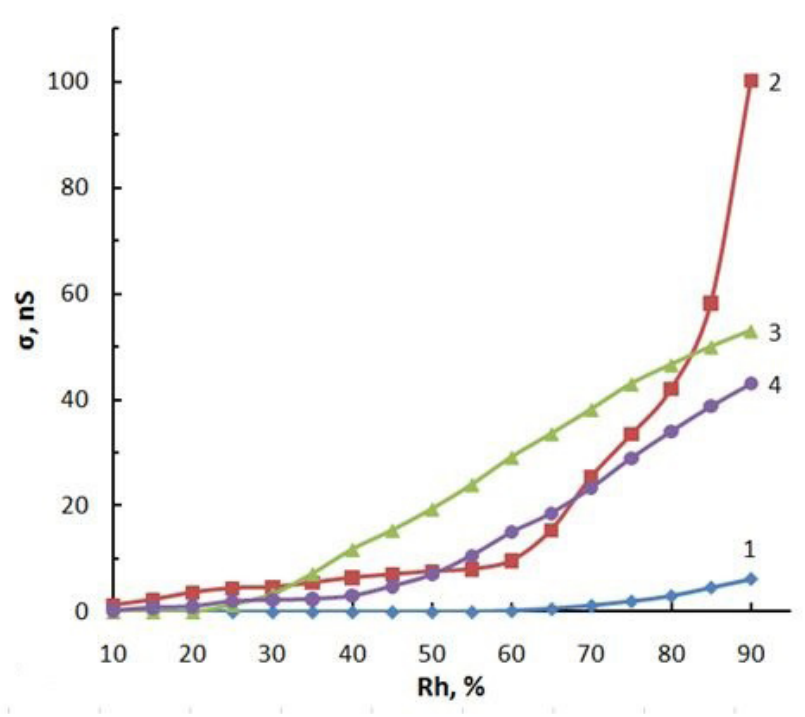

a

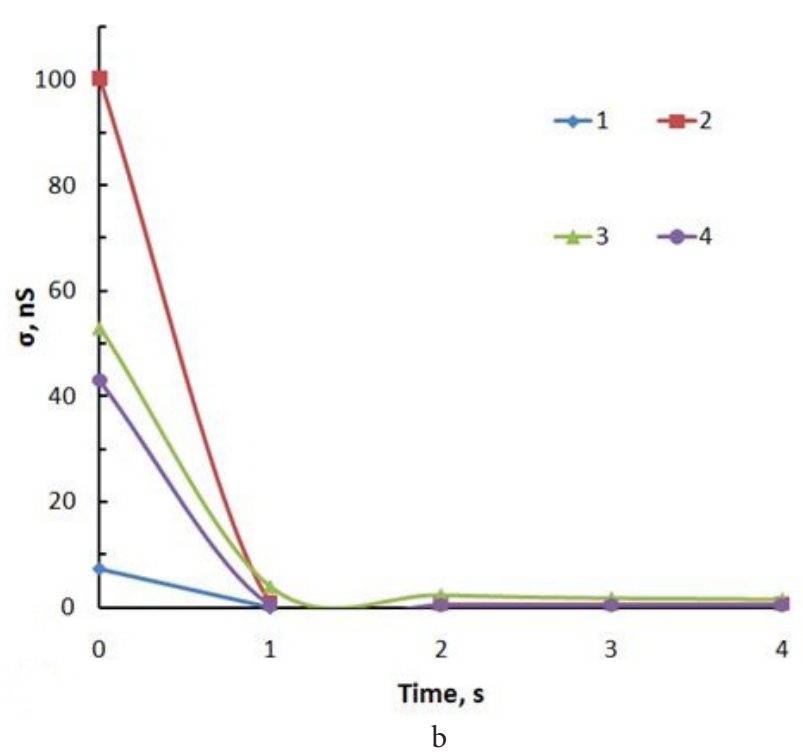

b

Fig. 6. (Color online) Dependences of the conductivity of films of PANI derivatives on humidity (a); recovery time of samples 1-4 (b).

conductivity. Samples of unmodified PANI demonstrate the lowest conductivity. It should be noted that resistive sensors on thin films $\mathbf{3}$ have the most uniform and closest to linear characteristics in the range of $20-90 \%$ humidity. The somewhat higher conductivity of sample 3 film compared to sample 4 can be explained, apparently, by the difference in polar properties of the substituents, presented in the orthoposition and associated with a greater dipole moment of the compound 3 than 4 .

The morphological features of the samples based on PANI (Fig. 5) also arise due to the presence of substituents of different nature in the ortho-position of the aromatic ring. For example, the presence of $\mathbf{2}$ monomeric ortho-toluidine units in the product with a hydrophilic methyl group on the one hand and a hydrophobic aromatic ring on the other gives the structure amphiphilicity. Such a structure, like the morphology considered above, is determined by the selfassembly method, which follows from the experimental conditions of the process [24]. The mechanism includes the initial formation of self-assembled monomer micelles, which are present at the initial stage of the reaction. At high humidity values (more than 60\%), the hydrophilic group (-CH3) protrudes outward and surrounds the aromatic ring, forming micelles [24-26]. The aggregation of such small monomeric micelles produces submicron groups that are templates for hollow polymer nanospheres. This, apparently, explains the increase in conductivity (Fig. 6a) and enlargement of size of the formed hollow nanospheres (Fig. $5 \mathrm{~b}$ ). The polarity of functional groups in aniline (cyclohec-2-en-1-yl- and cyclopent-2-en-1-yl-) modified in the position of the aromatic ring is close, but lower than for methylgroup, therefore, the formation of a supramolecular structure for the samples $\mathbf{3}$ and $\mathbf{4}$ decreases the conductivity and, as a consequence, the sensitivity to water vapor.

Indeed, the use of PANI as a detecting element of a sensor requires the creation of loose and well-permeable layers for the analyte with a high specific surface area $[27,28]$. The developed surface makes it possible to increase the sensitivity of the device, and the small thickness and high permeability of the layer provide a fairly quick establishment of equilibrium and a high measurement speed.

The time dependences of the recovery time of the film samples conductivity (Fig. 5b) with a sharp decrease in humidity by opening the test chamber cover (Fig. 3) reveal approximately the same values - about 1 second. Most likely, this time is associated with the processes of diffuse and convective equalization of humidity in the chamber and the surrounding space. In any case, the investigated resistive sensors demonstrate very low inertia and good response time.

\section{Summary}

On the basis of functionalized anilines we have synthesized a number of new (co)polymers by the method of oxidative polymerization. As a result of their study, the effect of the chemical structure and surface morphology of thin films of PANI and copolymers based on it on the electrical conductivity and sensory sensitivity was revealed. Determination of the electrical conductivity of the films at different values of air humidity revealed the possibility of their use in a sensor of relative air humidity. At the maximum value of the relative air humidity (90\%), poly(aniline-co-ortho-toluidine) films have the best conductivity, which is in good agreement with morphological studies.

Acknowledgements. The work was carried out within the framework of a state assignment (project No. AAAA-A19-119020890014-7).

\section{References}

1. A. A. Bunakov, A. N. Lachinov, R. B. Salikhov. Technical Physics. 48, 626 (2003). Crossref

2. R. B. Salikhov, A. N. Lachinov, R. G. Rakhmeyev. Journal of Applied Physics. 101, 053706 (2007). Crossref

3. R.B. Salikhov, A. N. Lachinov, A. A. Bunakov. Physics of the Solid State. 49, 185 (2007). Crossref

4. S. Manjunatha, T. Machappa, Y. T. Ravikiran, B. Chethan, 
A. Sunilkumar. Physica B: Condensed Matter. 561, 170 (2019). Crossref

5. S. Kundu, R. Majumder, R. Ghosh, M. Pradhan, S. Roy, P. Singha, D. Ghosh, A. Banerjee, D. Banerjee, M.P. Chowdhury. Journal of Materials Science. 55, 3884 (2020). Crossref

6. V.P. Anju, P. R. Jithes, S. K. Narayanankutty. Sensors and Actuators A. 285, 35 (2019). Crossref

7. F. Zeng, X. Liu, D. Diamond, K.T. Lau. Sensors and Actuators B. 143, 530 (2010). Crossref

8. M.V. Kulkarni, S. K. Apte, S.D. Naik, J.D. Ambekar, B. B. Kale. Sensors and Actuators B. 178, 140 (2013). $\underline{\text { Crossref }}$

9. L. Kumar, I. Rawal, A. Kaur, S. Annapoorni. Sensors and Actuators B. 240, 408 (2017). $\underline{\text { Crossref }}$

10. A.R.Tameev,A.V.Vannikov, R. G.Rakhmeev,A.N.Lachinov, V.R. Nikitenko, R. B. Salikhov, A.A. Bunakov. Physics of the Solid State. 53, 195 (2011). Crossref

11. L. Li, G. Li, W. Zhang, C. She, J. Lin, S. Liu, F. Yue, C. Jing, Y. Cheng, J.Chu. Materials Letters. 278,128438 (2020). Crossref

12. S. R. Jamnani, H. M. Moghaddam, S. G. Leonardi, G. Neri. Synthetic Metals. 268,116493 (2020). Crossref

13. I. B. Abdrakhmanov, A. G. Mustafin, B. M. Sharafutdinov. Claisen rearrangement among aromatic amines. Ufa, Gilem (2014) 168 p. (in Russian) [И.Б. Абдрахманов, А.Г. Мустафин, В.М. Шарафутдинов. Перегруппировка Кляйзена в ряду ароматических аминов. Уфа, Гилем (2014) 168 с.]

14. J. C. Chiang, A. G. MacDiarmid. Synthetic Metals. 13, 193 (1986). $\underline{\text { Crossref }}$
15. W. S. Huang, B. D. Humphrey, A. G. MacDiarmid. Journal of the Chemical Society, Faraday Transactions. 1, 2385 (1986). Crossref

16. A. G. MacDiarmid, J. C. Chiang, A. F. Richter, A. J. Epstein. Synthetic Metals. 18, 285 (1987). Crossref

17. T. Higuchi, K. A. Connors. Adv. Anal. Chem. Instrum. 4, 117 (1965).

18. P. Wang, K. L. Tan, F. Zhang, E.T. Kang, K. G. Neoh. Chemical Materials. 13, 581 (2001). Crossref

19. A. Kazuo. J. Polym. Sci. A Polym. Chem. 47, 2463 (2009). Crossref

20. A. Kazuo. Bulletin of the Chemical Society of Japan. 80, 649 (2007). Crossref

21. H. Goto, K. Akagi. Macromolecules. 35, 2545 (2002). Crossref

22. H. Jiang, Y. Geng, J. Li, X. Jing, F. Wang. Synthetic Metals. 84, 125 (1997). Crossref

23. J. Sui, L. Z. Zhang, H. Peng, J. Travas-Sejdic, P. Kilmartin. Nanotechnology. 20, 415606 (2009). Crossref

24. A. A. Isakova, O. L. Gribkova, A. D. Aliev, A. V. Indenbom, N. V. Shevlyakova, V. A. Tverskoy, A. A. Nekrasov. Physical chemistry of surfaces and protection of materials. 56, 406 (2020).

25. B. Gupta, R. Prakash. Macromolecular Chemistry and Physics. 213, 1457 (2012). $\underline{\text { Crossref }}$

26. P. Anilkumar, M. Jayakannan. Langmuir. 24, 9754 (2008). Crossref

27. M. A. Shishov, V.A. Moshnikov, I. Yu. Sapurina. Journal of Applied Chemistry. 86, 56 (2013).

28. M. A. Shishov, V.A. Moshnikov, I. Yu. Sapurina. Glass Physics and Chemistry. 37, 146 (2011). rossref 